\title{
Producing, Distributing and Using Manuscripts for Teaching Purposes at French, English and German Universities in the Late Middle Ages
}

\begin{abstract}
The essay aims to provide a short survey of the production and distribution of manuscripts for academic purposes at European universities in the late Middle Ages. It discusses access to and use of manuscripts, including hybrid situations in which students used private copies, consulted books in a library, or borrowed manuscripts for study. The essay then moves on to illustrate key teaching methods, above all dictation, and raises the question of what parameters we should take into account when reconstructing contexts of learning and teaching from manuscripts, especially when it comes to issues of layout and glossing.
\end{abstract}

The formation of universities in Europe in the High Middle Ages was a successful model for the organisation of advanced studies. One of the most demanding tasks of the new universities was to support their teaching staff and students by providing them with texts for learning purposes: manuscripts and, since the second half of the fifteenth century, printed books. Access to written texts has been essential throughout the medieval period, because 'education' - even at university level meant 'exercising tradition'. ${ }^{1}$ And this tradition was essentially laid down in authoritative texts, ${ }^{2}$ which had to be read, commented on and discussed in detail in the trivium, in the quadrivium of the artes liberales and in medicine, law and theology. In historical portrayals of universities, the aspects of producing, distributing and using manuscripts are generally addressed very briefly, if at all. Plenty of relevant information has been published in essays, however. Nonetheless, a differentiated overview is still missing, which is not surprising, as many questions still have not been resolved by researchers yet. This essay attempts to

1 Grubmüller 1989, 47: ‘Unterricht ist im Mittelalter Einübung in Tradition’.

2 Miethke 1990, 18: 'Grundlage des Unterrichts der scholastischen Universität sind [...] autoritative, schriftlich niedergelegte Texte oder Textcorpora [...]'.

๖ Open Access. (c) 2021 Michael Baldzuhn, published by De Gruyter. (cc) BY-NC-ND This work is licensed under the Creative Commons Attribution-NonCommercial-NoDerivatives 4.0 International License. https://doi.org/10.1515/9783110741124-005 
draw some baselines against this backdrop. It does not offer any new insights as such, but aims to provide a short survey on the production, distribution and use of manuscripts for academic purposes in the heart of Europe.

\section{The use and availability of manuscripts at universities}

Imagine a Carolingian monk sitting in a monastic scriptorium with a manuscript in front of him, making a copy of it for the monastery's library, the 'intellectual armoury' of the institution, 're-arming' it with the labour of his own hands and consequently fostering his own salvation and that of his clerical community. This is an idealised scenario, and one that is simplistic and needs some differentiation - for example with regard to the division of labour in a monastic scriptorium. ${ }^{4}$ But in view of the new universities of the High Middle Ages, it brings to mind the new dimensions of making manuscripts and texts available to a large readership. A student taking up employment at a university did not stay there for the rest of his life, but only temporarily. ${ }^{5}$ The texts and books he brought with him or wrote down or commissioned did not pass into the ownership of the monastic library, but remained his own, and the 'salvation' he sought was a more individual one, a more secular one ${ }^{6}$ - in any case more diversified with regard to different levels of education and academic degrees.

3 On the medieval dictum 'a monastery without books is like a castle without any weapons', see Silvestre 1964.

4 Division of labour was a common practice among, for instance, illuminators of manuscripts; see Jakobi-Mirwald 2004, 148-160.

5 It is a logical consequence that both vol. 1 and vol. 2 of the Geschichte der Universität in Europa address the paths of life and the mobility of students; see Rüegg 1993-1996, vol. 1, chaps 8-9, and vol. 2, chaps 9-10.

6 Cf. e.g. the statement of Haubrichs 1995, 70, with respect to books, monks and education in Carolingian times: 'Schreiben ist sakraler Dienst in der "Werkstatt der Tugenden”. [...] Schreiben hieß, dem Teufel Wunden zufügen'. ('Writing is sacred service in the "workshop of virtues”. [...] Writing meant to injure the devil'), or the little anecdote reported in the first half of the twelfth century by Ordericus Vitalis in his Historia ecclesiastica: 'ein recht sündiger Mensch hätte seine Seele retten können, weil Gott jede Sünde mit einem geschriebenen Buchstaben aufrechne und in diesem Fall gerade ein Buchstabe übrig geblieben sei' ('a sinful man saved his soul, because god charged his sins with every single letter written by him and in this case just a single letter remained') (Goetz 2002, 78). The close connection between devotion and studium in the monastic culture up to the twelfth century has been pointed out emphatically by Illich 1991, 15-66, who 
A modern observer would expect universities to face the new requirement for providing manuscripts, the rising number of scholars, ${ }^{7}$ the large amount of texts required and the new range of subjects to be covered by a central library for the whole universitas magistrorum et scholarum. But although central libraries at or near universities can be considered 'die fortschrittlichste Bibliotheksgattung des späten Mittelalters' ('the most advanced type of library of the late Middle Ages'), ${ }^{8}$ they more or less remained 'klein und wissenschaftlich unbedeutend' ('small and scientifically unimportant') up to the eighteenth century. ${ }^{9}$ Libraries belonging to colleges - of which Paris, the most important city in Europe with a university, had about 70 at the end of the Middle Ages - and those belonging to individual faculties were of far more importance in structural terms. They were only complemented slowly by central libraries. In England, following French examples, they arose 'gradually'. ${ }^{10}$ At the University of Prague, established in 1348, the Collegium Carolinum, founded 1366 by Emperor Charles IV, was richly provided with manuscripts. Heidelberg had a university library right from the start. In contrast, Oxford did not obtain a central library until 1412, Leipzig, founded in 1409, possessed no library at all in the fifteenth century, and in Rostock, founded in 1419, only collections belonging to the faculties were available initially. So expecting a central library to exist is evidently a fairly modern idea.

On the other hand, university statutes sometimes required new students to possess key texts upon enrolment, especially students of law and theology. ${ }^{11}$ This point needs to be differentiated further with respect to individual disciplines. Students of art at Oxford for example were not obliged to possess the manuscripts needed. ${ }^{12}$ And what is more, we have to take into account the heterogeneous skills of the new students arriving at their faculty of arts: several of them still needed

re-reads Hugos of St Victor's Didascalicon and separates its didactics from future scholastic teaching-practices.

7 It is generally important to bear in mind a huge mismatch between the number of people enrolled on a course of studies and those who actually finish their studies and obtain an academic degree. Numerical data on university enrolment and examinations is provided for the German-speaking territories by Schwinges 1986. For references to relations in France, see Miethke 1990, 13, n. 24.

8 Vorstius and Joost 1980, 17 (see 17-18 and 24).

9 Ridder-Symoens 1996, esp. 170.

10 Vorstius and Joost 1980, 18.

11 With respect to Oxford, see Weichselbaumer 2010, esp. 23: ‘[...] mussten die Juristen bei der Immatrikulation beschwören, Kopien des Digestum novus, des Infortiatum und des Libellus Institutionum zu besitzen'. For further relevant references, see Miethke 1990, 18-19 and n. 38-39.

12 Cf. Weichselbaumer 2010. 
elementary instruction in Latin ${ }^{13}$ and hardly were able to write the texts they needed by themselves. All in all, however, all this different groups of students had to organise themselves how they would acquire the manuscripts with the key texts they needed.

It is not surprising that against this backdrop - no central libraries supporting the students, different requirements of the faculties, varying skills of the students to write the texts by themselves - the use of manuscripts in the academic lectio often has been a colourful affair. This is reflected in the prominent illustration by Laurentius de Voltolina (Fig. 1) in the second half of the fourteenth century to accompany Henricus de Alemannia's Liber ethicorum, that gives insights on a medieval university lecture. Although idealised - the master who is reading is Aristoteles himself - it mirrors late medieval reality in showing different types of students in the room: some with books, some sharing their book with a neighbour, some using slips of parchment and others without anything in written form in front of them at all, just listening to the master and relying on their memory.

This hybrid situation did not change until the advent of printed books and their growing availability due to prices falling. But printed books also led to a further problem that also had to be solved by educational institutions, teachers and students: the standardization of their texts. A note that Maturin Cordier (1479-1564) wrote in a dedication letter addressed to the Parisian printer Robert Estienne (1503-1559) and introducing his Latin-French edition of the Late Antique Disticha Catonis printed by Estienne in 1533 reports that Cordier initially planned to dictate the antique text and his own annotations to his students in order to provide them with the material they needed. However, he noticed that his dictations needed further correction. So he decided to get them printed to receive a homogeneous textual basis for his pupils. ${ }^{14}$

If we look back on teaching and education in the manuscript age the tardiness of the universities regarding the standardization of texts used in the academic lectio is astonishing. It was not until the last quarter of the fifteenth century that the university regulations at Leipzig University stated that students attending a lectio not only had to bring their own text along with them, but that the text needed to be proprius and accomodatus (apart from that, up to three students were permitted to share a single manuscript: possunt tamen duo aut tres ad maximum eodem textu pro tempore uti simul). ${ }^{15}$ Supplying students with appropriate (!)

13 Cf. Hajnal 1959 and Gabriel 1951.

14 The passage from the Latin text is cited and paraphrased by Baldzuhn 2009, vol. 1, 362-363.

15 Cf. Zarncke 1861, 399, 405, 465, 473, 481. The use of different editions of printed books by the masters and students in Leipzig has been analysed paradigmatically by Jensen 2004, esp. 458- 
texts was therefore a demanding exercise at university level, although 'Universität und Schrift sozusagen ex definitione ganz unmittelbar zusammen [gehören]'16 ('university and the use of writing belong together by definition') and it remained demanding even when the printing press grew more popular in the late fifteenth century, even at Leipzig University, where teachers and students were more experienced in using the new 'black art' for their needs than anywhere else in Europe. ${ }^{17}$

\section{Lending manuscripts, consulting library- manuscripts}

In the first few decades of university teaching, urban religious houses provided the best conditions in which to solve the problem of manuscript support. For one thing, they already had libraries that their studying conventuals could use: since at least according to the Summa magistri bull issued by Pope Benedict XII in 1336, all of the monastic orders have been encouraged to send suitably qualified members to a university. ${ }^{18}$ Personal property was not allowed among Franciscans, but they were allowed to make use of other possessions - such as books. Dominicans were not only allowed to own books, but their order even supplied conventuals with money to buy them. Books were lent to conventuals for their instruction, even for unlimited periods. They accompanied their temporary owners on their travels, were corrected by them, supplemented, kept up to date, and later they were returned not only to their former library, but to libraries at other locations where their fraternity had settled down. The Franciscan library in Oxford had a particular section called libraria studencium, for instance, which was separate from the libraria conventus. Some of its manuscripts were borrowed numerous

489. Academic lectiones usually have been prepared by the teaching masters in close cooperation with the book printers in an ad hoc fashion; the university as a book-ordering authority enters the scene only since the beginning of the sixteenth century: cf. Zarncke 1861, 463.

16 Miethke 1990, 7.

17 'Keine andere europäische Universität dieser Zeit hat eine ähnlich umfangreiche, innovative und vielgestaltige Druckproduktion hervorgebracht, weder Paris noch Köln, weder Rom noch Bologna; in Erfurt, Greifswald, Heidelberg, Oxford, Prag, Rostock und anderen Hochschulstädten gab es kaum nennenswerte oder gar keine Druckaktivitäten': Eisermann 2009, 161-162. 18 See Parkes 1996. 
times, showing traces of frequent use over a long period and even the names of their changing owners. ${ }^{19}$

Like the religious orders, numerous colleges were able to maintain their scholarship holders. ${ }^{20}$ Many colleges were required by their benefactors to house students, guide them in their daily life and support their studies directly. Additional exercises and lectures were held at several colleges, and they provided manuscripts to their members. The statutes of the Collège de Hubant (or 'de l'Ave Maria'), which was founded by Jean de Hubant in 1339 and was located at the Parisian monastery of Sainte-Geneviève, required the manuscripts borrowed by the six scholarship holders to be periodically checked to see if they were still intact. A manuscript of the statutes draws attention to this obervatio librorum with a miniature illustration of its own (Fig. 2). ${ }^{21}$ The Collegium sapientiae in Freiburg, founded by Johannes Kerner in 1497, only ran a reference library for its students. The loaning of manuscripts was only intended to be an exception - miniatures in the manuscript with the statutes show the library twice and point out the special character of a reference library (Fig. 3). ${ }^{22}$ The Collegium Porta coeli or Amplonianum in Erfurt was even created because of the huge amount of manuscripts - a contemporary catalogue lists more than 600 volumes - donated to the Faculty of Arts by Amplonius Ratinck in 1412. Only a little later, eight grants for students (these eventually grew to twenty) completed Amplonius' donation. ${ }^{23}$

\section{Book trade and peciae}

Compared with the use of existing libraries or the foundation of new ones, the book trade taking place in university environments represents a more modern way of supporting scholars with manuscripts. The production of manuscripts was based on commercial considerations, and with the makers of manuscripts and their traders, new agents appeared who had to arrange things with the masters of the university and the institution itself. The book trade in Paris has been explored quite intensively to date. Most of the Parisian manuscript producers and

19 On English documents, see Parkes 1996, 123, n. 17.

20 For an overview of the college system, see Gieysztor 1993, esp. 115-118 the chapter on 'Kollegien'.

21 Cf. François 1942-46; Pellegrin 1948; Gabriel 1955, esp. 166-170. Gabriel refers to similar practices at other Parisian colleges (de Sorbonne, de Bayeux, de Cluny, d'Harcourt).

22 Kerer 1957. For details of the library, see the companion volume of the facsimile, 93-94.

23 Paasch and Döbler 2001. The library catalogue has been edited; see Lehmann 1969, 1-99. 
sellers worked in the Rue Neuve Notre-Dame, where the process of producing one single manuscript could be divided between up to a dozen scribes, rubricators and illuminators. Sometimes they all lived at close quarters and their work was done in families over several generations. They did not only provide scholars with manuscripts, but also members of the local court, and even the King. Local monasteries were clients as well. Manuscript-makers set up libraries to loan manuscripts to people, especially scholars. ${ }^{24}$ These stationarii, as they were known, had to collaborate with the students' masters and in particular with the university administration. This is expressed in an oath reported August 1302, which had to be performed by the librarii (Juramenta librariorum sive stationariorum). Among other things, this states: quod ipsi stacionarii librorum utilium pro studio cujuscunque facultatis exemplaria [...] procurabunt. ${ }^{25}$ The University of Paris turned to the pergamenarii, ${ }^{26}$ the manufacturers of parchment, in February 1291 and to the librarii and stationarii as early as $1275 .{ }^{27}$ In 1304 a university commission in Paris made up of representatives from all four faculties codified a list of 150 texts that were allowed to be distributed in the way described (quod debent habere librarii pro exemplari commodato scholaribus) and it set their price as well. ${ }^{28}$ Paris had fourteen sworn booksellers in 1368 and more than 24 of them in 1488.

The list of texts from 1304 additionally calls to mind a very special, medieval way of producing schoolbooks. The prominent work of Aegidius Romanus written to teach young princes is listed as De regimine principum, xliij pecias [...] xxxij den[arii]. ${ }^{29}$ The term pecias deserves some attention here: it refers to individual parts of a manuscript that could be borrowed separately and used as models for new copies, normally for one or two weeks, and that could be paid for separately as well. This made it possible for pupils to produce their own exemplars of a text used for teaching purposes by replicating it themselves (alternatively, they could pay a scribe to produce a copy for them). Manuscripts written down in parts this way can be identified by corresponding notes at the end of their respective parts, which had to ensure a correct continuation of the text.

24 Cf. the study of Rouse and Rouse 2000 about commercial book producers in medieval Paris. For maps and a more differentiated view now, see Fianu 2006.

25 Denifle 1889-1897, vol. 2, no. 628, 97-98.

26 Denifle 1889-1897, vol. 2, no. 575/575a, 49-52.

27 Denifle 1889-1897, vol. 1, no. 462, 532-534: Ordinatio universitatis Parisiensis de librariis sive stationariis.

28 Denifle 1889-1897, vol. 2, no. 641, 107-112.

29 Denifle 1889-1897, 111. 
It was Jean Destrez who first did some research into manuscripts and their peciae in $1936 .{ }^{30}$ In Paris, peciae were well known in the late thirteenth century, but they were originally used in Bologna, presumably in the 1220s. The peciae system spread from Northern Italy to France, Spain and England (but only in Oxford). It did not reach Portugal, the south of Italy or the German-speaking countries, though ${ }^{31}$ - all the manuscripts from there containing pecia notes are actually imports. The Faculty of Medicine at the University of Bologna established the system in 1405, but this was an atypical occurrence. The system employed in Italy until then had almost only been used for juridical manuscripts, ${ }^{32}$ while the peciae system in the rest of Europe had already declined by that point: 'For reasons unknown it was abandoned in the fifteenth [century]'.33 There is no single explanation for this decline, but one of the relevant facts could be the increasing spread of paper - in 1389, the first paper mill north of the Alps had been established by Ulrich Stromer near Nuremberg in Germany. ${ }^{34}$ From the fourteenth to the fifteenth century, the relation between manuscripts written down on paper and those written on parchment reversed from 70:30\% to $30: 70 \% .^{35}$ One can observe a striking rise in the number of manuscripts produced since the 1270 s. $^{36}$ Generally, it seems that the acquisition of books for learning purposes could increasingly be arranged by the pupils and students themselves.

30 Destrez 1936. Also see Christ 1938. For an excellent overview now, see Weichselbaumer 2010, esp. 1-29.

31 See the map in Weichselbaumer 2010, 9.

32 On the stock of texts distributed in the form of peciae, see Murano 2005.

33 Derolez 2003, 30.

34 Schneider 2014, 112. For the broader context, see Tschudin 2012. Parchment was four times more expensive than paper in the second half of the fourteenth century, and later on, in the second half of the fifteenth, it was as much as thirteen times dearer (cf. Schneider 2014, 110, n. 22).

35 Exact figures are stated in Needham's article on book production on paper and vellum in the fourteenth and fifteenth centuries: Needham 2015, esp. 69-270. The percentages were calculated by Kümper 2014, 166. Parchment was used for printed books, too, however, but only in exceptional cases: in representative and precious books or editions of texts made for frequent use, such as school texts. Needham 2016, 256, has counted around fifty editions of the Donat and similar texts on grammar printed on parchment between 1470 and 1500.

36 Cf. the diagram given by Neddermeyer 1998, 657 ('Die absolute Handschriftenproduktion in Europa 1250-1530'). 


\section{Dictation: reportatio, pronuntiatio, dare ad pennam}

However, none of this explains the strange fact that the pecia system was not introduced in the educational environment of Central European universities, which had been established since the middle of the fourteenth century (in 1347 in Prague, 1364 in Cracow, 1365 in Vienna, 1379 in Erfurt, 1385 in Heidelberg and in 1388 in Cologne), a fact that Karl Christ noticed in his important essay from 1938: the German university statutes do not say anything about stationarii and so do not talk of them with respect to the production of manuscripts. Rather, they take into account the dictation of texts, i.e. the activities of pronuntiare and ad pennam dare. ${ }^{37}$ In addition, they sometimes use the term reportatio ('dictation'), but all in all, the terminology they employ is not always very clear, and all regulations that have come down to us relate to a 'special type of lesson/event' established for this main purpose: providing students with the texts they needed for the lectio their teachers would be conducting later on. Reportationes were mainly held by scholars of a lower degree - baccalarii, for example, who dictated ad pennam (quill) to their assembled students. This was a regular practice in Prague, Vienna, Heidelberg, Erfurt, Ingolstadt and Leipzig, hence the statutes referred to it and attempted to control and arrange it in a particular way. ${ }^{38}$ As for other universities (and certain advanced Latin schools in larger cities as well), reportationes are mentioned in the colophons that scribes added to their manuscripts. This is the case in Cracow, Biblioteka Jagiellońska, Cod. 2460, for instance (which contains Thomas of Erfurt's Novi modi significandi and the Fabulae Aviani, amongst other texts); this was written down in the middle of the fifteenth century at the Cracow university and partly dictated (see fols $87^{\mathrm{r}}-173^{\mathrm{v}}$ ), it says: pronunciata per Baccalarium Paulum De Raczusz. ${ }^{39}$ This is also the case in

37 See Christ 1938, 36-39 and Wattenbach 1896, 562-565. A considerable number of relevant documents have been collected by Bernd Michael in his PhD thesis: Michael 1985, 263-267. On terminology, see Teeuwen 2003, 253-255 (dictare, pronuntiare) and 333-335 (reportare, reportatio, reportator). Palaeographical conclusions based on the distribution of texts via dictation have been drawn by Gerhardt Powitz 2005a. Udo Kühne at the Institut für Klassische Altertumskunde in Kiel has drawn up a 'repertory of dictated medieval manuscripts': <https://www.klassalt.unikiel.de/de/projekte/forschung_alt/mittel-und-neulatein-forschung/201erepertorium-diktierterhandschriften-des-mittelalters201c> (accessed on 18 Nov. 2020).

38 Cf. Christ 1938, 36-39, Wattenbach 1896, 562-565, and, concerning Leipzig, Zarncke 1861, 458 (fourth edition of the statutes in 1499/1522).

39 For more on this manuscript, see Baldzuhn 2009, 572-573. 
Tübingen, University Library, Mc. 328 (containing the Vocabularius ex quo), which was written down in the middle of the fifteenth century at the Latin school in Ulm, South Germany and dictated in full (fols $2^{\text {ra }}-209^{\text {vb }}$ ) by the fourth assistant teacher there (the locatus) to the student Heinrich Heller: finita est iste liber et lecta de quarto locato in vlma per me hainricum hellerum de tuwingen tunc temporis scolaris vlme..$^{40}$

The last example concerns vocabulary that is hardly likely to have been read aloud, but was probably used as a dictionary. It emphasises the fact that texts for lessons were not the only things copied in the way described above. In fact, one should distinguish between single dictations that took place in an ad hoc manner (possibly in an academic environment) and dictations for groups of students that were organised in a more institutionalised way. This distinction has not always been borne in mind by researchers, however. Indeed, manuscript research has neither analysed medieval colophons with respect to this distinction yet nor systematically identified manuscripts written down by way of dictation at all. ${ }^{41}$

Last but not least, numerous other questions also need to be resolved. For one thing, it seems odd that just the University of Paris tried to prevent its masters from reading out their lectiones too slowly: a bid to prevent the degradation of the lectio to an occasion where it became necessary for students to make copies of lectures and texts themselves, which they had done ever since the fourteenth century, even though we can often find a well-established book trade in the background, particularly in Paris. ${ }^{42}$

\section{The layout of manuscripts: mise-en-page}

Manuscript research conducted in recent decades has focused strongly on the layout of medieval European manuscripts ${ }^{43}$ and shown that the mise-en-page of a text was not only a question of arrangement and aesthetical design, but that the

40 For more details about the manuscript, see Bodemann and Dabrowski 2000, esp. 25. Bodemann and Dabrowski 2000, 31-32 refer to five more manuscripts dictated in Ulm.

41 Colophons in German medieval manuscripts will be studied in a project supported by the DFG starting 2021 at the Christian-Albrechts-Universität zu Kiel (Margit Dahm, Timo Felber): <https://www.germanistik.uni-kiel.de/de/lehrbereiche/aeltere-deutsche-literatur/forschung/ dfg-projekt-kolophone> (accessed on 18 Nov. 2020). The collections of colophons provided by the Bénédictins du Bouveret 1965-1982 are incomplete.

42 Cf. the remarks in Miethke 1990, 22-25.

43 An important impulse came from the essays collected in Martin and Vezin 1990. 
history and tradition of the text, its placing on a manuscript page and the circumstances of the manuscript's production and distribution are all closely related. These aspects therefore have to be analysed as well and understood with respect to these close relations. Outlining the most relevant types of layouts used for academic texts is impossible in this short essay. ${ }^{44}$ Rather, I shall try to illustrate the correlations mentioned above using just three examples: (1) Wolfenbüttel, Herzog August Bibliothek, Cod. Guelf. 13.10 Aug. 4º (2) Erfurt, Universitäts- und Forschungsbibliothek Erfurt/Gotha, Dep. Erf. CA. $4^{\circ} 21$ and (3) Berlin, Staatsbibliothek zu Berlin - Preußischer Kulturbesitz, Ms. Lat. Quart 536. All of them lead us to the study of Latin grammar, a basic requisite for pupils and students.

A collection of fables written by the Late Antique author Avianus - 42 pieces in elegiac distichs - was used for grammar instruction in Europe from Carolingian times, if not earlier. It was covered in academic contexts up to the end of the Late Middle Ages. ${ }^{45}$ The manuscript now preserved in Wolfenbüttel (Fig. 4$)^{46}$ shows us the text in a typical form: every verse has its own, new line. This form was employed by scribes throughout the Middle Ages - and for a huge amount of works by other literary authors as well, which served as thesauri providing examples of rhetorical issues, Latin grammar (litterae) and proper conduct, worldly wisdom and wise behaviour (mores). Likewise, supplementary explanations on the basic text are included in a way found in countless other manuscripts of classical authors (and in countless other manuscripts at the faculties of arts) throughout the Middle Ages: inter lineas, between the single verses. The arrangement of longer explanations that did not fit between the verses seems less self-evident, though. The introduction to these 'commentaries', for example, was placed at the top of the page in the Wolfenbüttel manuscript and forms two blocks that look like two horizontal and interlaced ' $L$ ' letters. Short parts with commentaries are placed in the margins. This arrangement only became a standard one in advanced studies of the auctores in the course of the thirteenth century. Consequently, it is the default version used in a large number of manuscripts mainly of French and English provenience called Libri Catoniani, for example, which add five more Latin texts to the Fabulae (Fig. 5). ${ }^{47}$

44 For corresponding images drawn from medieval manuscripts, see esp. Weijers 1996. Gerhard Powitz has attempted to give late medieval layouts of texts with commentaries a typology in his article Powitz 2005b.

45 For more on the medieval history of the text and its transmission, see Baldzuhn 2009, 22-134.

46 The manuscript is discussed in detail in Baldzuhn 2009, 810-814.

47 Attention was drawn to the Liber Catonianus - the name is related to the Disticha Catonis, which begin the collection - by Boas 1914. Regarding the - presumably French - academic genesis and the French and English diffusion of the Liber, see Baldzuhn 2009, 90-105. 
It is obvious that a layout like the one in the Wolfenbüttel manuscript is unsuitable for dictation. In fact, it requires the skills of an experienced scribe who had to copy it in a more 'depicting' way than just by writing it down. In particular, the balanced allocation of the little blocks of prose to the commentaries in the margins had to be kept in mind because they had to be placed near the verses they refer to.

A manuscript with the Fabulae currently kept in Erfurt and probably written at the university there in the second half of the fourteenth century shows the text with a completely different layout (Fig. 6)..$^{48}$ The differences are not as much in the verses of the main text and its interlinear glosses as in the commentary. This is a completely independent block of text that does not accompany the verses in the margins at all, but follows each fable after its last verse. The commentary consequently interrupts the course of the basic text and breaks it up. It is not by chance that the layout appears to be more cohesive and fluid in this manuscript. Currently, it seems that this kind of layout was not developed until the second half of the fourteenth century. It seems to have been particularly popular in German-speaking countries and was presumably developed just for the distribution of texts via dictation. Instead of encountering several short blocks of text with lengthy annotations, we find a block written in prose. And the individual annotations it contains are now connected syntactically. Furthermore, a commentary of the given type could now reach a random length: Interposing it between the fables only postpones the following fable, moving it further down - without any restriction of the manuscript page and its margins. The question of how interlinear glosses found their way onto the paper cannot be discussed here in detail, unfortunately, but they frequently seem to have been dictated as well. ${ }^{49}$

It is not clear who was responsible for this general redesign and reformulation of commentaries in the German countries in the fourteenth century. Perhaps it was the locati at urban Latin schools and the baccalarii at the universities who dictated the texts. If so, were they sufficiently educated to perform this challenging task effectively, I wonder?

A similar fundamental step in the reorganisation of layouts of manuscripts containing texts by literary auctores had been made two hundred years earlier, in the twelfth century (which is often called the 'century of commentary') and the following century as well. New commentaries on auctores, formerly circulating in separate manuscripts without the basic verse texts (cf. Fig. 7), were combined in a single manuscript along with the texts they referred to and were arranged

48 For more details about the manuscript, see Baldzuhn 2009, 522-527.

49 Cf. Baldzuhn 2005 and the manuscript described by Baldzuhn 2009, 110-115. 
together with them on a single page. This procedure cannot be discussed here in any detail,,$^{50}$ but the question arises here again: who was it who came up with the new page layouts found in manuscripts such as the one in Wolfenbüttel and the several Libri Catoniani?

An obvious way of combining a text written in verse in one manuscript and its commentary written in another is binding them both together in a single volume. ${ }^{51}$ A solution that is rather more original can be found in the third manuscript from Berlin: text and commentary have been written down in two parallel columns. ${ }^{52}$ The main task, however, was to position the individual sections of the commentary so they all matched up with the verses of the main text to which they referred. This required detailed knowledge of both the basic text and its commentary - especially if an explanation did not refer to a single verse, but to general qualities of the text as a whole (such as discussing its author or general literary, grammatical or rhetorical features). Arranging a text and its commentary in a particular way always meant the commentary had to be of a certain length; copies made later, such as individual minutes from a master's lecture, could not simply be adapted at will.

\section{Lectio: practical use of manuscripts}

Numerous incunable prints of school texts attracted their potential purchasers with a woodcut at the front, illustrating the ideal situation in which it was to be used: the so-called Magister cum discipulis woodcut that shows a teacher with a book in front of him on his desk, talking to his students during the lectio (Fig. 8). ${ }^{53}$ Researchers' perspectives on the relation between the oral lectio and written text with all its glosses and commentaries changed significantly over the last century: in a unique move in 1905, Alfred Heubaum firmly rejected a popular disregard of manuscript material by researchers on the history of education. ${ }^{54}$ Considering the number of school manuscripts that were in use and the ample information often

50 More on this issue can be found in Baldzuhn 2009, 69-90.

51 See the manuscript containing the Fabulae produced in the second half of the fourteenth century in Germany, which is now kept in Lübeck: Bibliothek der Hansestadt, Ms. Philol. $8^{\circ} 14$ (esp. fols $29^{\mathrm{r}}-38^{\mathrm{v}}$ and fols $38^{\mathrm{v}}-42^{\mathrm{r}}$ ); cf. Baldzuhn 2009, 619-621.

52 The manuscript was written in the second half of the thirteenth century in Germany (esp. fols $\left.1^{\mathrm{va}}-13^{\mathrm{r}}\right)$; see Baldzuhn 2009, 461-466.

53 On this widespread type of illustration, see Schreiber and Heitz 1908.

54 Heubaum 1905. 
provided in a single manuscript replete with dense annotations, many researchers hoped to gain far-reaching insights into the medieval classroom from studying them. There was a common illusion at the time that manuscripts almost allowed one to look over the medieval schoolmaster's shoulder. ${ }^{55}$ But in recent decades, detailed studies on glosses and commentaries have shown that these types of texts are by no means the result of individual lessons. On the contrary, annotations - just like the main text - are determined by a binding textual history of their own. The history of their transmission, especially with respect to interlinear glosses, could even vary more than the history of the instructional text itself..$^{56}$ At the same time, the sensitivity to medial differences in the designs of oral and written accounts increased, and at least the sensitivity for the fact that the orality of the speech and the presence of the teacher remain a core feature of the academic lectio..$^{57}$ The use of writing is undeniable, but still, school manuscripts, to put it bluntly, are only secondary 'sources': 'Spiegelung der mündlichen Kommunikation in einem anderen Medium' ('reflection of oral communication in another medium'). ${ }^{58}$ Bearing this medial complexity in mind, we can also gain a broader impression of the specific semantics of medieval descriptions of media in educational contexts. These semantics should definitely be examined as a field of their own. In general, and even in academic treatises on the human senses, medieval descriptions seem to be based on a rhetoric of immediacy ${ }^{59}$ and show a characteristic resentment to the use of writing by pupils. At the end of the thirteenth century, for example, Hugo of Trimberg, a schoolmaster in Bamberg, bemoaned: 'Sît man schuolbuoch in die hant / Krumpte und durch die gürtel want, / Sît wart unmêre schuolmeister lêre, / Ir lôn, ir fürderunge und ir êre'. ${ }^{60}$ And a short treatise on oral conversation written in the second half of the fifteenth century is unable to accept that the life of students should be determined by

55 See Oskamp for just one - arbitrary - example: 'And so the schoolteacher's hand in MS Plut. 78.19 in the Laurentian Library not only gives us an opportunity to look in during the lessons, but also shows us the frustrations of a twelfth-century teacher who has put so much unnecessary work into preparing his lessons' (Oskamp 1977, 197).

56 Cf. the editors preface in Grubmüller 2000, 8-9.

57 This has been pointed out by Miethke 1990.

58 Cf. Michael 2006, esp. 185. The metaphor of a mirror used by Michael is misleading, however.

59 Cf. Michael 2006, 188-189.

60 'Ever since manuscripts have been used by pupils the teaching of the masters has been treated with contempt [...]': Hugo von Trimberg, Der Renner, ed. Ehrismann 1970, verses 1647716480. Verses 16765-16768 point in a similar direction: ‘(Von schuolern): Sô kumt aber einer und siht hin în, / Der koufet schœniu büechelîn, / Diu er mit im ze lande füere / Und nimmer mêr si denne gerüere'. ('On pupils: There are several of them buying eesome manuscripts and carry them around and never ever make any use of them'). 
reading. Trying to put it more precisely, the author claims they 'listen', not 'read' - nevertheless the following question, what they are listening to, is answered with a list of texts (circulating in written form, of course): 'Es tu scolaris?' - 'Sum.' 'Quid legis?' - 'Non lego, sed audio.' 'Quid audis?' - 'Tabulam vel Donatum vel Alexandrum vel logicam vel musicam' ${ }^{61}$

Essentially, the paradigmatic change of perspective requires a change in our prior expectations: we should no longer initially expect a school manuscript to report oral facts. On the contrary, we should only expect a written artefact accompanying oral communication in a certain way, which always has to be specified in detail - if not, in marked contrast to minutes, an artefact even pre-structuring the oral lectio.

This change in the first point of view tallies with several other observations. Records of academic lectiones are generally 'extremely rare finds', just as Bernd Michael has said. ${ }^{62}$ Individual manuscripts demonstrate again and again that a first layer of written components with the basic text, glosses and commentary almost always contains most of the substantial elements; the scribes did not leave any gaps to be filled in later on. Blank space for additional texts is more frequent at the end of the Middle Ages - in texts designed for printing; these present the basic text with wide margins for commentary and wide line spacing to allow for glosses, both of which were expected to be added in handwritten form. ${ }^{63}$ Academic manuscripts from the fourteenth and fifteenth centuries with a layout optimised for dictation sometimes contain additions, most of which are written in the margins, but these additions are nearly always small-scale ones compared to the dense explanations offered initially. This, at least, is the impression one gets from late medieval examples containing the Fabulae.

In contrast, we more often find later additions in manuscripts from the thirteenth and fourteenth centuries, especially in those from France and England. One example is the Wolfenbüttel manuscript cited above, which also contains Ovid's Metamorphoses; there are more than a dozen different hands that inserted

61 The citation is from the edition by Melchior Lotter and Konrad Kachelofen published in Leipzig in 1496 (Gesamtkatalog der Wiegendrucke, no. 9411, fol. A3r [punctuation added by me]). 62 Michael 2006, 182, n. 10. Also see the even more cautious formulation on page 185, n. 18: 'Über den Weg scholastischer Lehre von der mündlichen Form zur Verschriftung, sofern sie überhaupt stattfand, ist wenig bekannt' [my own emphasis]. ('We know little about the transfer of oral scholastic knowledge into written forms - if this transfer even took place').

63 For more on these prints designed especially with respect to academic lectures, cf. Nickel 1989 and Leonhardt 2004. 
their additions between the lines and in the margins. ${ }^{64}$ This is only my first impression, but it might be explained by the different ways of producing and distributing academic manuscripts. Being a product of dictation, a manuscript may have tended to stay in the hands of its first writer and owner, who saw little need to make any additions to it. On the other hand, manuscripts produced and distributed in a 'more written way' seem to have switched their owners more frequently.

At present, however, a statement of this type needs to be backed up by reliable empirical data, which is still lacking. Corresponding studies are therefore essential in future. It should also be kept in mind that every single manuscript that has come down to us is of a very fragile representativeness. ${ }^{65}$

\section{References}

Baldzuhn, Michael (2005), ““dem selbigen glosiert er allwegen in die feder”. Distribution und Produktion/Rezeption volkssprachlicher "expositio ad litteram” im Umfeld des spätmittelalterlichen Trivialunterrichts', in Elizabeth Andersen, Manfred Eikelmann and Anne Simon (eds), Texttyp und Textproduktion in der deutschen Literatur des deutschen Mittelalters, Berlin: De Gruyter, 415-435.

Baldzuhn, Michael (2009), Schulbücher im Trivium des Mittelalters und der Frühen Neuzeit. Die Verschriftlichung von Unterricht in der Text- und Überlieferungsgeschichte der 'Fabulae' Avians und der deutschen 'Disticha Catonis', Berlin: De Gruyter.

Bénédictins du Bouveret (1965-1982), Colophons de manuscrits occidentaux des origines au XVIe siècle, 6 vols, Münster: Aschendorff.

Boas, Marcus (1914), 'De librorum Catonianorum historia atque compositione', Mnemosyne, n.s., $52: 17-46$.

Bodemann, Ulrike and Christoph Dabrowski (2000), 'Handschriften der Ulmer Lateinschule. Überlieferungsbefund und Interpretationsansätze’, in Klaus Grubmüller (ed.), Schulliteratur im späten Mittelalter, Munich: Fink, 11-47.

Christ, Karl (1938), 'Petia. Ein Kapitel mittelalterlicher Buchgeschichte', Zentralblatt für Bibliothekswesen, 55: 1-44.

Denifle, Heinrich (ed.) (1889-1897), Chartularium universitatis Parisiensis, 4 vols, Paris:

Culture et Civilisation.

64 Wolfenbüttel, Herzog-August-Bibliothek, Cod. Guelf. 13.10 Aug. $4^{\circ}$ (France, last quarter of the thirteenth century). See the description of the manuscript in Baldzuhn 2009, 810-814, esp. 814 (die Glossen 'in verschiedenen Schichten von verschiedenen Händen [...] weiter aufgefüllt. In den Metamorphosen begegnet man solchen Nachträgen besonders oft' - glosses added in several steps by several hands; in the Metamorphoses such additions are widespread). 65 This fundamental methodological problem has been addressed by Esch 1985. 
Derolez, Albert (2003), The Paleography of Gothic Manuscript Books. From the Twelfth to the Early Sixteenth Century, Cambridge: Cambridge University Press.

Destrez, Jean (1936), La 'pecia' dans les manuscrits universitaires du XIII' et du XIV' siècle, Paris: Jaques Vautrain.

Eisermann, Falk (2009), 'Die schwarze Gunst. Buchdruck und Humanismus in Leipzig um 1500', in Enno Bünz and Franz Fuchs (eds.), Der Humanismus in Leipzig. Akten des in Zusammenarbeit mit dem Lehrstuhl für Sächsische Landesgeschichte an der Universität Leipzig, der Universitätsbibliothek Leipzig und dem Leipziger Geschichtsverein am 9./10. November 2007 in Leipzig veranstalteten Symposiums, Wiesbaden: Harrassowitz, 149-179.

Ehrismann, Gustav (ed.) (1970), Hugo von Trimberg, Der Renner, Berlin: De Gruyter.

Esch, Arnold (1985), 'Überlieferungschance und Überlieferungszufall als methodisches Problem des Historikers', Historische Zeitschrift, 240: 529-570.

Fianu, Kouky (2006), 'Métiers et espace. Topographie de la fabrication et du commerce du livre à Paris (XIIle-XVe siècle)', in Godfried Croenen and Peter Ainsworth (eds), Patrons, Authors and Workshops. Books and Book Production in Paris around 1400, Louvain: Peeters, 21-46.

François, Michel (1942-1946), 'Les statuts du collège de Hubant', Les Trésors des Bibliothèques de France, 26: 97-106.

Gabriel, Astrik L. (1951), 'Preparatory teaching in the Parisian colleges during the fourteenth century', Revue de l'Université d'Ottawa, 21: 449-483.

Gabriel, Astrik L. (1955), Student Life in Ave Maria College, Mediaeval Paris. History and Chartulary of the College, Notre Dame, IN: University of Notre Dame Press.

Gesamtkatalog der Wiegendrucke, hrsg. von der Kommission für den Gesamtkatalog der Wiegendrucke, vols 1-8/1, Leipzig: Hiersemann, 1925-1940; hrsg. von der Deutschen Staatsbibliothek zu Berlin, vols 8/2-, Stuttgart: Hiersemann, 1978-.

Goetz, Hans-Werner (2002), Leben im Mittelalter vom 7. bis zum 13. Jahrhundert, 7th edn, München: Beck.

Grubmüller, Klaus (1989), 'Mündlichkeit, Schriftlichkeit und Unterricht. Zur Erforschung ihrer Interferenzen in der Kultur des Mittelalters', Der Deutschunterricht, 41/1: 41-54.

Hajnal, István (1959), L'enseignement de l'écriture aux universités médiévales, 2nd edn by László Mezey, Budapest: Maison d'Édition de l'Académie des Sciences de Hongrie.

Haubrichs. Wolfgang (1995), Die Anfänge: Versuche volkssprachiger Schriftlichkeit im frühen Mittelalter (ca. 700-1050/60), 2nd edn, Tübingen: Max Niemeyer.

Heubaum, Alfred (1905), 'Die mittelalterlichen Handschriften in ihrer Bedeutung für die Geschichte des Unterrichtsbetriebes', Mitteilungen der Gesellschaft für deutsche Erziehungs- und Schulgeschichte, 15: 1-6.

Illich, Ivan (1991), Im Weinberg des Textes. Als das Schriftbild der Moderne entstand, Frankfurt/M.: Luchterhand.

Jakobi-Mirwald, Christine (2004), Das mittelalterliche Buch. Funktion und Ausstattung, Stuttgart: Reclam.

Jensen, Kristian (2004), 'Exporting and importing Italian humanism. The reception of Italian printed editions of classical authors and their commentators at the University of Leipzig', Italia medioevale et umanistica, 45: 437-497.

Kerer, Johannes (1957), Statuta collegii sapientiae. Satzungen des Collegium Sapientiae zu Freiburg im Breisgau 1497. Faksimile-Ausgabe, Lindau, Konstanz: Thorbecke.

Kümper, Hiram (2014), Materialwissenschaft Mediävistik. Eine Einführung in die Historischen Hilfswissenschaften, Paderborn: Schöningh. 
Lehmann, Paul (ed.) (1969), Mittelalterliche Bibliothekskataloge Deutschlands und der Schweiz, vol. 2, Munich: Beck.

Leonhardt, Jürgen (2004), 'Gedruckte humanistische Kolleghefte als Quelle für Buch- und Bildungsgeschichte', Wolfenbütteler Notizen zur Buchgeschichte, 29: 21-34.

Michael, Bernd (1985), Johannes Buridan. Studien zu seinem Leben, seinen Werken und zur Rezeption seiner Theorien im Europa des späten Mittelalters, PhD thesis, Freie Universität Berlin, 1985.

Michael, Bernd (2006), 'Textus und das gesprochene Wort. Zu Form und Theorie des mittelalterlichen Universitätsunterrichts', in Ludolf Kuchenbuch and Uta Kleine (eds), 'Textus' im Mittelalter. Komponenten und Situationen des Wortgebrauchs im schriftsemantischen Feld, Göttingen: Vandenhoeck \& Ruprecht, 179-206.

Miethke, Jürgen (1990), Die mittelalterlichen Universitäten und das gesprochene Wort, Munich: Stiftung Historisches Kolleg.

Martin, Henri-Jean and Jean Vezin (eds), Mise en page et mise en texte du livre manuscrit, Paris: Éditions du Cercle de la Librarie - Promodis.

Murano, Giovanna (2005), Opere diffuse per exemplar e pecia, Turnhout: Brepols.

Neddermeyer, Uwe (1998), Von der Handschrift zum gedruckten Buch. Schriftlichkeit und Leseinteresse im Mittelalter und in der frühen Neuzeit. Quantitative und qualitative Aspekte, Wiesbaden: Harrassowitz.

Needham, Paul (2015), 'Book production on paper and vellum in the fourteenth and fifteenth centuries', in Carla Meyer, Sandra Schultz and Bernd Schneidmüller (eds), Papier im mittelalterlichen Europa. Herstellung und Gebrauch, Berlin: De Gruyter, 247-273.

Nickel, Holger (1989), 'Mit Durchschuß. Zu Preisrelationen im Buchwesen der Inkunabelzeit', in Zur Arbeit mit dem Gesamtkatalog der Wiegendrucke. Vorträge der Internationalen Fachtagung vom 26. bis 30. November 1979 in Berlin, Berlin: Deutsche Staatsbibliothek, 127136.

Oskamp, Hans P. A. (1977), ‘A Schoolteacher’s Hand in a Florentine Manuscript', Scriptorium, 31: 191-197.

Paasch, Kathrin and Eckehard Döbler (eds) (2001), Der Schatz des Amplonius. Die große Bibliothek des Mittelalters in Erfurt. Begleitbuch zur gleichnamigen Ausstellung der Stadt- und Regionalbibliothek Erfurt in Zusammenarbeit mit dem Angermuseum Erfurt vom 2.9. bis 4.11.2001, Erfurt: Stadt und Regionalbibliothek.

Parkes, Malcom B. (1996), 'Buchversorgung und Buchgebrauch in den Ordenshäusern der Oxforder Universität', in Christel Meier, Dagmar Hüpper and Hagen Keller (eds), Der Codex im Gebrauch (Akten des Internationalen Kolloquiums 11.-13. Juni 1992), Munich: Fink, 109-126.

Pellegrin, Élisabeth (1948), 'La bibliothèque du collège de Hubant dit de l'Ave Maria à Paris', Bibliothèque de l'École des Chartes, 107: 68-73.

Powitz, Gerhardt (2005a), 'Modus scolipetarum et reportistarum. Pronuntiatio und die Studentenkursive des 15. Jahrhunderts', in Gerhardt Powitz, Handschriften und frühe Drucke. Ausgewählte Aufsätze zur mittelalterlichen Buch- und Bibliotheksgeschichte, Frankfurt/M.: Klostermann, 43-56.

Powitz, Gerhardt (2005b), 'Textus cum commento', in Gerhardt Powitz, Handschriften und frühe Drucke. Ausgewählte Aufsätze zur mittelalterlichen Buch- und Bibliotheksgeschichte, Frankfurt/M.: Klostermann, 57-81.

Rouse, Richard Hunter and Mary A. Rouse (2000), Manuscripts and Their Makers. Commercial Book Producers in Medieval Paris, Turnhout: Brepols. 
Rüegg, Walter (ed.) (1993-1996), Geschichte der Universität in Europa, Vol. 1: Das Mittelalter; Vol. 2: Von der Reformation bis zur Französischen Revolution (1500-1800), Munich: C. H. Beck.

Schneider, Karin (2014), Paläographie und Kodikologie für Germanisten. Eine Einführung. Third revised edition, Berlin: De Gruyter.

Schreiber, Wilhelm Ludwig and Paul Heitz (1908), Die deutschen 'Accipies' und Magister cum discipulis-Holzschnitte als Hilfsmittel zur Inkunabel-Bestimmung, Strasbourg: J. H. E. Heitz.

Schwinges, Rainer (1986), Deutsche Universitätsbesucher im 14. und 15. Jahrhundert. Studien zur Sozialgeschichte des Alten Reiches, Stuttgart: Steiner.

Silvestre, Hubert (1964), 'A propos du dicton "claustrum sine armario quasi castrum sine armamentario"', Medieval Studies, 26: 351-353.

Teeuwen, Mariken (2003), The Vocabulary of Intellectual Life in the Middle Ages, Turnhout: Brepols.

Tschudin, Peter (2012), Grundzüge der Papiergeschichte, 2nd edn, Stuttgart: Hiersemann. Vorstius, Joris and Siegfried Joost (1980), Grundzüge der Bibliotheksgeschichte, 8th edn, Wiesbaden: Harassowitz.

Wattenbach, Wilhelm (1896), Das Schriftwesen im Mittelalter, 3rd edn, Leipzig: S. Hirzel.

Weichselbaumer, Nikolaus (2010), 'Die Pecienhandschriften des Zisterzienserklosters Heilsbronn', Archiv für Geschichte des Buchwesens, 65: 1-87.

Weijers, Olga (1996), Le maniement du savoir. Pratiques intellectuelles à l'époque des premières universités (XIIIe-XIVe siècles), Turnhout: Brepols.

Zarncke, Friedrich (ed.) (1861), Die Statutenbücher der Universität Leipzig aus den ersten 150 Jahren ihres Bestehens [...], Leipzig: S. Hirzel. 


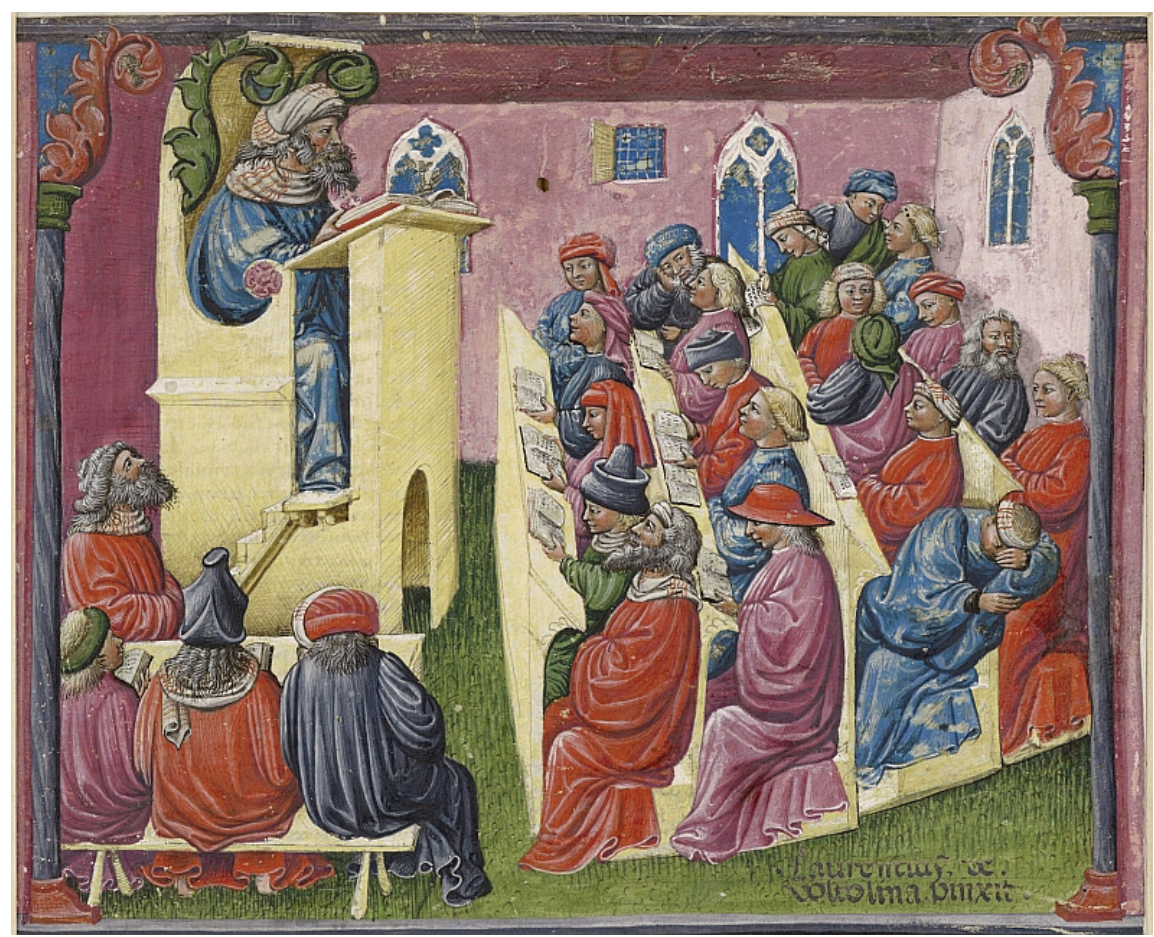

Fig. 1: Aristoteles giving a lecture in front of his students (miniature illustration, Italian, 2nd half of the fourteenth century); Berlin, Kupferstichkabinett, Min 1233; CC-BY-NC-SA. 


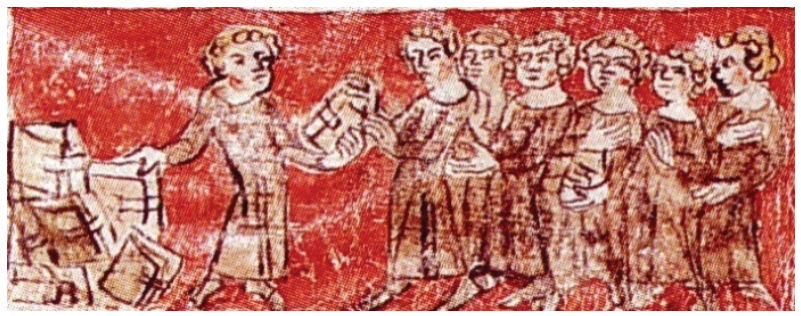

Fig. 2: Ostentatio librorum of manuscripts lent by scholars of the Collège de Hubant in Paris (miniature illustration, French, 2nd half of the fourteenth century); Paris, Archives nationales, MM 406, fol. 10v; CC-BY-NC-SA.

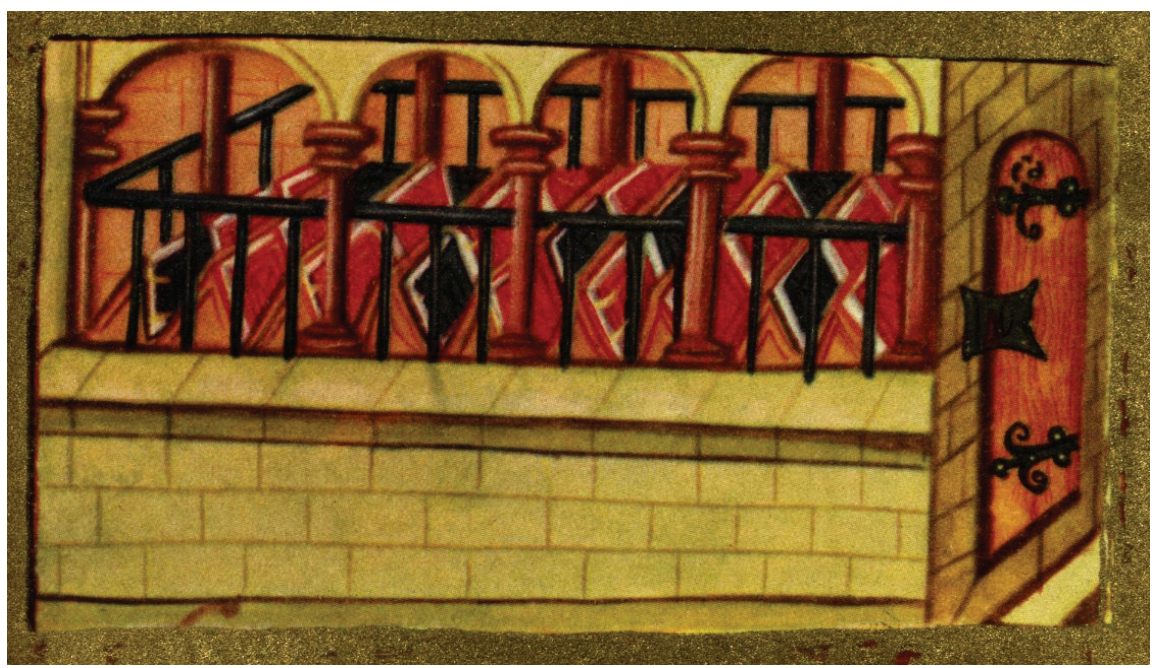

Fig. 3: Reference library for students at the Collegium sapientiae in Freiburg im Breisgau (miniature illustration, German, 1497); Freiburg, Universitätsarchiv, A 105/8141, fol. 44; (c) Universitätsarchiv, Freiburg i.B. 


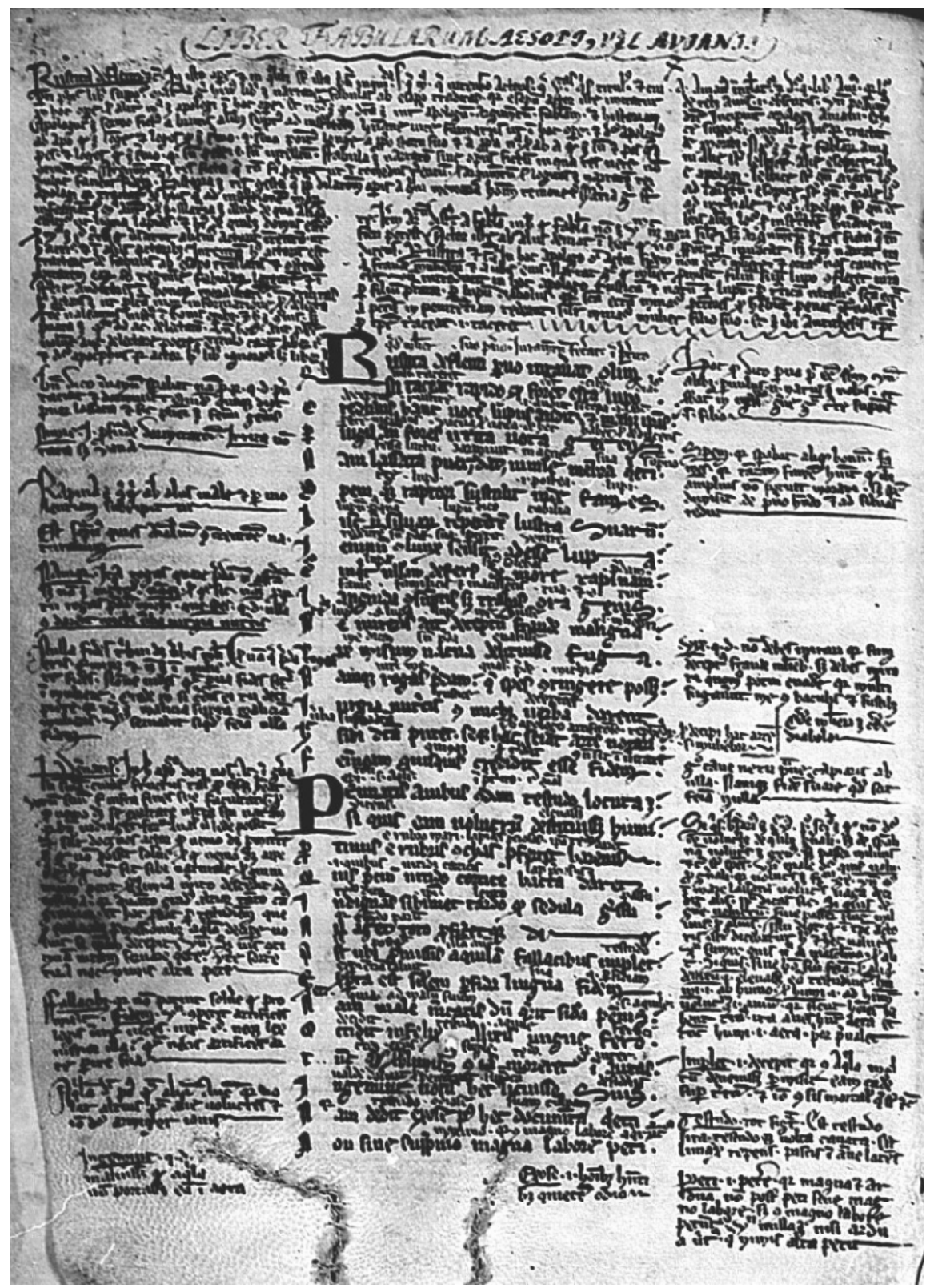

Fig. 4: Beginning of the Fabulae Aviani with basic text in verses, commentary in prose and interlinear glosses (French manuscript, last quarter of the thirteenth century); Wolfenbüttel, Herzog August Bibliothek, Cod. Guelf. 13.10 Aug. $4^{\circ}$, fol. 157; ; Herzog August Bibliothek, Wolfenbüttel. 

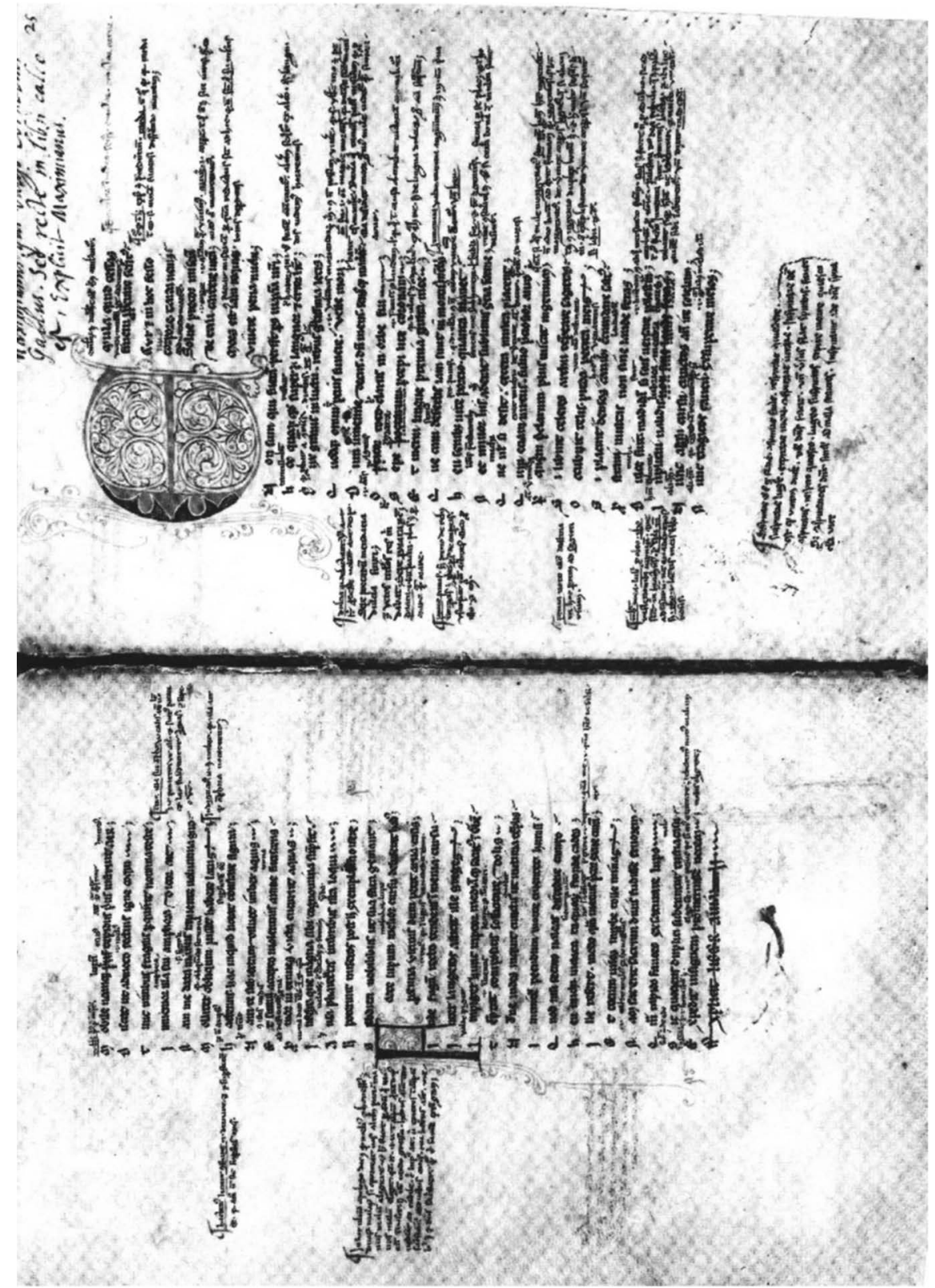

Fig. 5: End of the Fabulae Aviani and beginning of the Elegiae of Maximianus in a uniformly designed Liber Catonianus (French manuscript, end of the thirteenth century); Vatican City, Biblioteca Apostolica Vaticana, Reg. lat. 1556, fols $24^{\mathrm{v}}-25^{\mathrm{r}}$; @ Biblioteca Apostolica Vaticana, Vatican City. 


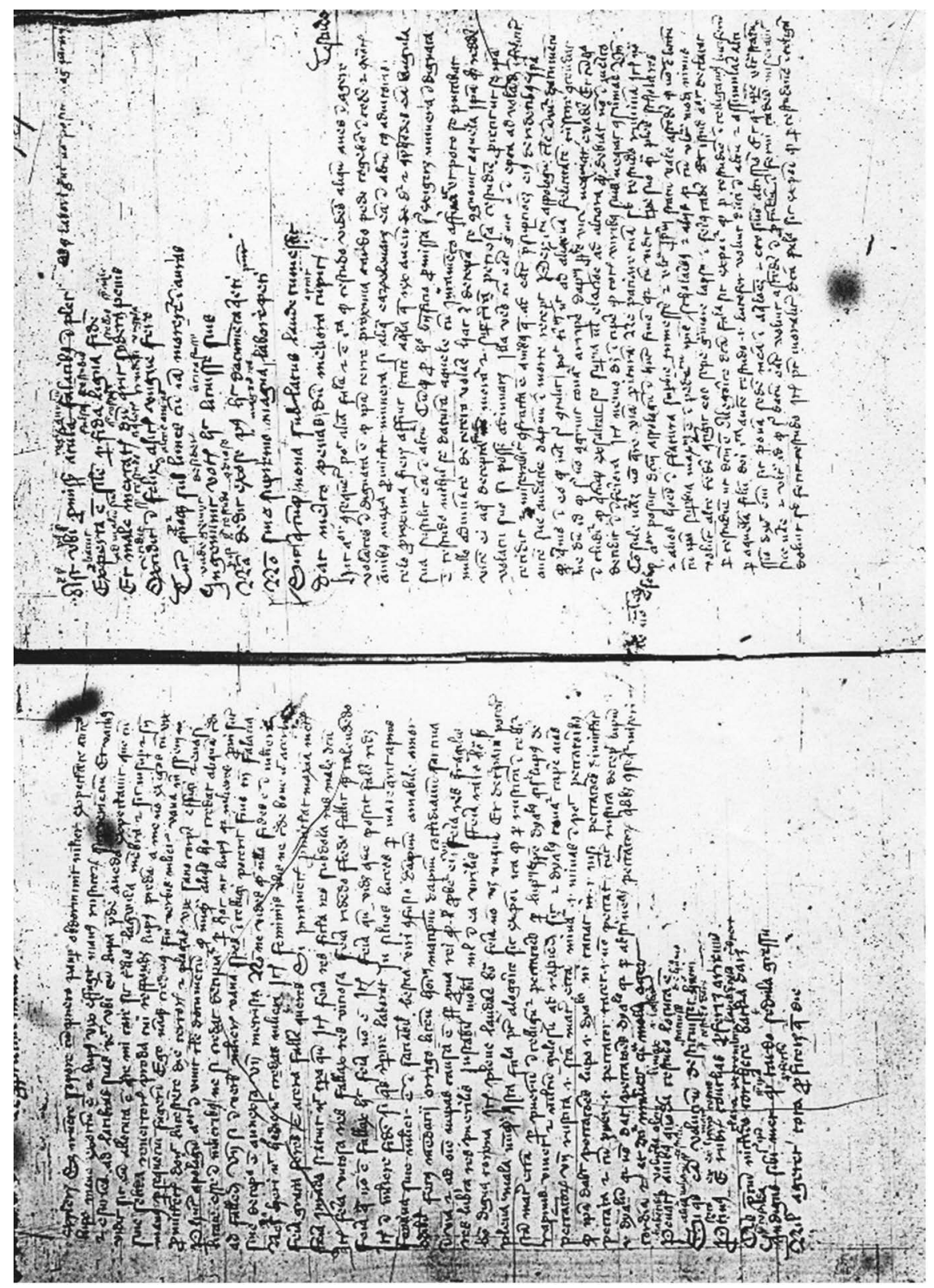

Fig. 6: Verses from the Fabulae Aviani with commentary in prose in a layout designed for dictation (German manuscript, third quarter of the fourteenth century); Erfurt, Universitätsund Forschungsbibliothek Erfurt/Gotha, Dep. Erf. CA. $4^{\circ} 21$, fols $18^{v}-19^{r}$; (C) Universitäts- und Forschungsbibliothek, Erfurt. 


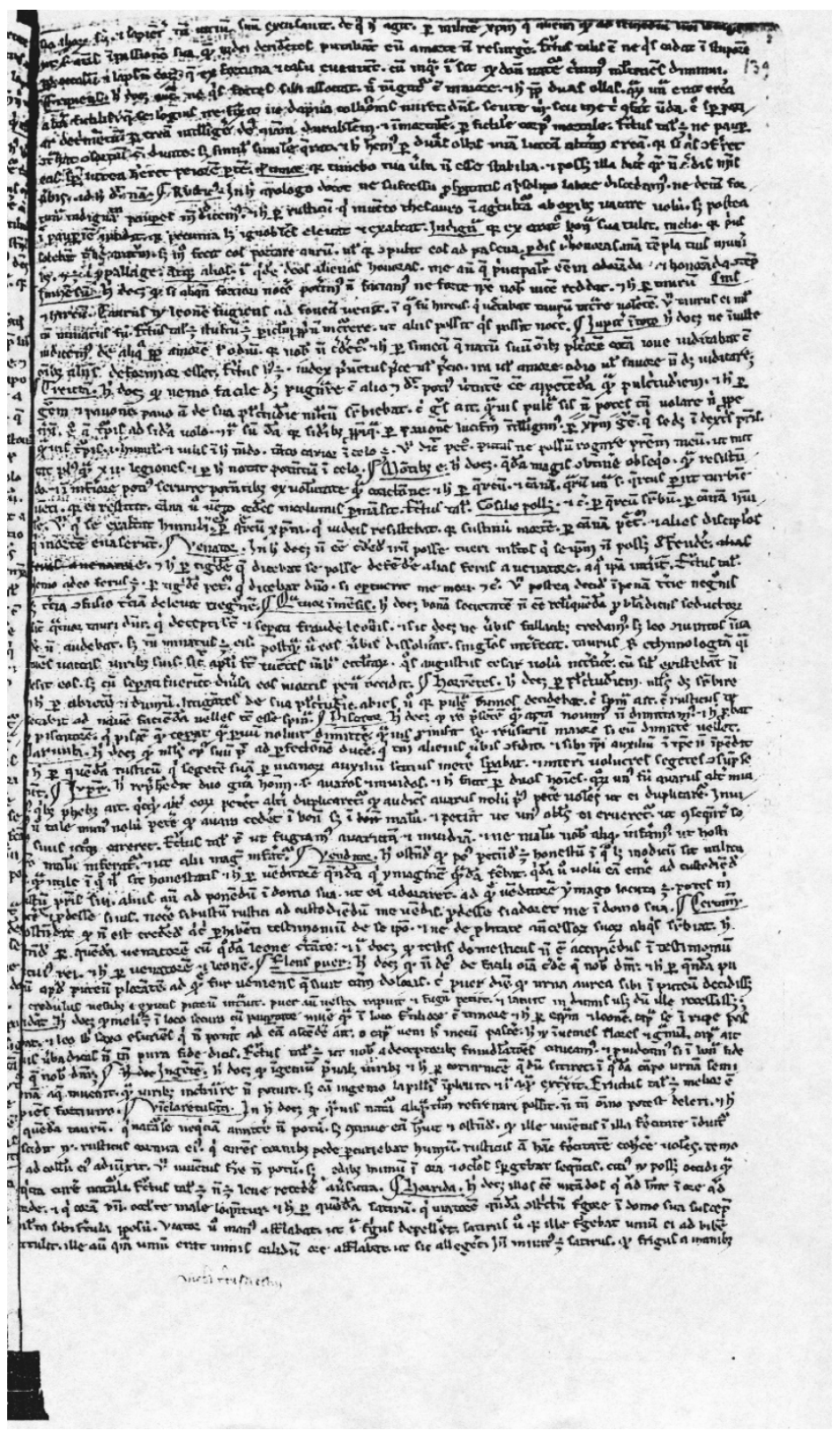

Fig. 7: Commentary in prose on the Fabulae Aviani without verses (German manuscript, second half of the thirteenth century); Copenhagen, Kongelike Bibliotek, Gl. Kgl. Samling $19054^{\circ}$, fol. 139'r ; C Kongelike Bibliotek, Copenhagen. 


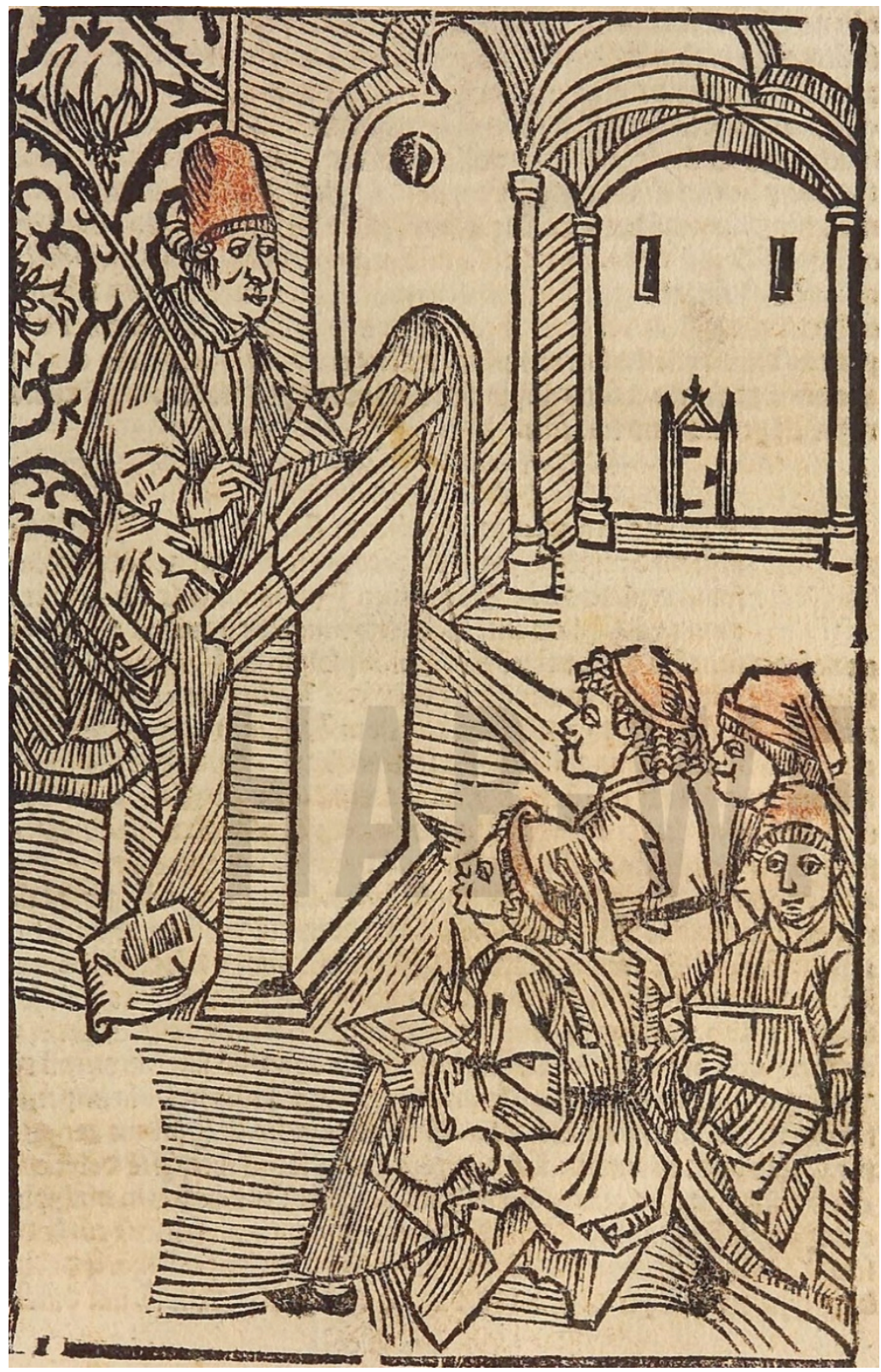

Fig. 8: Magister cum discipulis, woodcut opening a printed edition of the Disticha Catonis in Cologne 1497; Gesamtkatalog der Wiegendrucke, no. 6314, fol. A1 ${ }^{\text {r }}$; CC-BY-NC-SA. 